\title{
Dynamic transfer of soil bacteria and dissolved organic carbon into small streams during hydrological events
}

\author{
Florian Caillon $^{1,2} \cdot$ Jakob Schelker ${ }^{1,2}$ (D)
}

Received: 16 September 2019 / Accepted: 11 March 2020 / Published online: 19 March 2020

(c) The Author(s) 2020

\begin{abstract}
Small headwater streams interlink catchment soils with the river network. As water makes its way from the hillslopes to the stream, it may transport dissolved organic carbon (DOC) and potentially soil microbes into stream water. In this study, we aimed at quantifying the dynamic transfer of DOC and microbial life, namely bacteria from catchment soils into streams. We hypothesized that increased soil saturation enhances the lateral inflow of bacteria and DOC into streams. To address this hypothesis, we sampled six first order streams and three soil transects at two different depths located within the pre-alpine Oberer Seebach (OSB) catchment in Austria over a duration of 2 years. We found a strong variation in DOC concentrations (range $0.4-5.6 \mathrm{mg} \mathrm{L}^{-1}$ ) and bacterial abundances (range $<500,000-3,863,000$ cells $\mathrm{mL}^{-1}$ ) measured by flow-cytometry. The highest values of DOC and bacterial cells occurred during high flow events. DOC concentration and bacterial abundance were correlated across all streams and seasons. In soils, DOC ranges were higher and were also correlated with bacterial abundance, while DOC concentrations were $\sim 10$ times higher per bacterial cell than in streams. Overall we show that soils provide a dynamic inflow of bacteria and DOC to first order streams. Most probably, this results in a dynamic and reoccurring inoculation of small streams from catchment soils during runoff events. We propose that this dynamic microbial inoculation of small streams is potentially relevant for microbial community dynamics of downstream receiving waters.
\end{abstract}

Keywords Soil inoculation $\cdot$ Soil bacteria $\cdot$ Dissolved organic matter $\cdot$ Hydrological events

\section{Introduction}

Small headwater streams are dynamic systems that interlink the terrestrial landscape with the fluvial network (Battin et al. 2008; Richardson and Danehy 2007). As they receive water from hillslopes, they have been proposed as 'mirrors of the landscape', integrating the catchment heterogeneity of soils, geology and land-use into a combined biogeochemical signature (Bishop et al. 2008; Wipfli et al. 2007). Typically, headwater streams encompass $60-80 \%$ of stream networks flow length (Benda et al. 2005; Schumm 1956). As they provide nutrients, woody debris, and dissolved and particulate organic carbon (DOC and POC, respectively) to downstream

Jakob Schelker

jakob.schelker@univie.ac.at

1 Division of Limnology, Department of Limnology and Bio-Oceanography, University of Vienna, 1090 Vienna, Austria

2 WasserCluster Lunz / Biological Station GmbH, 3293 Lunz am See, Austria water bodies (Gomi et al. 2002; Wipfli et al. 2007), they play a crucial role for the ecology of downstream river networks. Also, through matter transport, headwater streams link the terrestrial and aquatic carbon cycle (e.g., Fasching et al. 2014; Raymond et al. 2013; Schelker et al. 2016). It is therefore critical to assess the ecology of headwater streams to understand the functioning of the rest of the river network.

Despite the important role headwaters play in aquatic networks, they remain understudied. Most first order streams are not fully represented on current maps (Benda et al. 2005). Also, headwater streams are influenced by environmental change (Wipfli et al. 2007). The strong link they share with terrestrial environment affect in particular stream DOC concentrations that show fluctuations throughout the year-being lower during winter and higher during summer (Dawson et al. 2008; Laudon et al. 2011). These seasonal variations are influenced by discharge and temperature as secondary drivers that are also sensitive to climate change (Köhler et al. 2009; Sidle et al. 2000). Similar to DOC, bacterial population dynamics, such as for example the bacterial 
abundances in streams show recurring seasonal patterns (Hullar et al. 2006).

DOC provides carbon and energy for bacterial heterotrophs (Williams and Del Giorgio 2005). Its variation influences bacterial biogeography (Findlay et al. 2008) and stream metabolism (Berggren and del Giorgio 2015). In some aquatic systems, the prevalence of major bacterial clades has been shown to be significantly modified by the presence and composition of DOC (Amaral et al. 2016). Thus, variations in DOC and bacterial abundances throughout the year support the dynamic nature of headwater streams. However, the origin of these variations is hitherto not well understood.

Soils constitute one of the most important microbial habitats, containing a great diversity of bacteria. The microbes have crucial roles in nutrient cycling, maintaining soil fertility and soil carbon sequestration (Fierer 2017; Philippot et al. 2013; Wagg et al. 2014). Soil microbes have a significant effect on biological processes as they produce $\mathrm{CO}_{2}$ while respiring soil organic matter, influence soil acidity and regulate soil dynamics (Fierer 2017). Within soils, microbial densities vary greatly. Microbial biomass is commonly one to two orders of magnitude lower in deeper soil horizons than at the soil surface (Federle et al. 1986; Fierer et al. 2003; Taylor et al. 2002).

Soils are connected to river networks by water flows that enter small streams through the riparian zone (Richardson and Danehy 2007; Sidle et al. 2000). The relationship between soils and streams has been extensively studied regarding the seasonal variation in DOC concentrations. In forested catchments, snowmelt and storms mobilize DOC from the surrounding soils that reaches the streams through subsurface flow-paths and induce an increase in stream DOC concentration (Fasching et al. 2015; Laudon et al. 2004). At the same time, soils have been proposed to serve as critical reservoirs and thus source areas of microbes for surface waters (Crump et al. 2012; Hullar et al. 2006). The transport of microbes from soils to small streams was previously shown using DNA sequencing techniques and this transfer has been hypothesized to alter downstream microbial communities (Crump et al. 2012; Ruiz-González et al. 2015; Savio et al. 2015). Bacterial transfer to streams was also shown to vary throughout the year and in response to changes in temperature and precipitation (Hassell et al. 2018; Hermans et al. 2019; Teachey et al. 2019). However, DNA sequencing data do not provide quantitative information and, to this day, little is known about the dynamics and seasonality of bacterial abundances in small headwater streams (Richardson 2019).

Here we propose that the dynamic connectivity between soils and streams acts as a principle origin of variation of bacterial abundances in headwater streams. To our knowledge, no previous study has analysed bacterial abundances in soil water from catchment soils in order to compare it to nearby headwater streams and shed light on their transient connectivity. Thus we aim to explore the dynamic link between soils and headwater streams in terms of DOC and bacterial abundances through time and at different flow conditions. We pose the following questions for this study: What is the soil contribution in terms of providing DOC and microbial life to small headwater streams? What are the temporal dynamics of these provisions? We hypothesize that DOC concentrations co-vary with bacterial abundances, as both are mobilized from the soil simultaneously. In addition, we propose that varying flow conditions and soil saturation influence the degree of connectivity between soils and streams and thus control the DOC concentrations and bacterial abundances in small streams.

\section{Methods}

\section{Study site}

Sampling was carried out on six small headwater streams draining into Lake Lunz located in the eastern Alps near Lunz am See, Austria (Fig. 1). Lake Lunz receives most of its water from the Oberer Seebach Catchment. This catchment is approximately $25 \mathrm{~km}^{2}$ and is largely pristine. Vegetation is dominated by Fraxinus excelsior, Acer pseudoplatanus, Fagus sylvatica, Salix caprea and Picea abies (Battin 1999; Fasching et al. 2015). During 2018, air temperature averaged $8.96{ }^{\circ} \mathrm{C}$ and precipitation averaged $1500 \mathrm{~mm}$. Snow cover can extend from November to May, but in some winters little snow is present. Between May 2010 and August 2013, the Oberer Seebach had an average DOC concentration of $1.56 \pm 0.3 \mathrm{mg} \mathrm{L}^{-1}$ during autumn and of $1.79 \pm 0.4 \mathrm{mg} \mathrm{L}^{-1}$ during summer (Fasching et al. 2015). The catchment is characterized by glacial alluvial deposits, which are underlain by a low-permeability layer of ancient lake sediment and calcareous rock (Battin 1999).

Three hillslopes around Lake Lunz were selected for this study (Rehberg, RBG; Schlögelberg, SBG; and the WasserCluster Lunz slope, WCL; Fig. 1). On each hillslope, two headwater streams were chosen, referred to as RBG2 and 3; SBG1 and 2; and WCL1 and 2. The streams are of first stream order, small in size (width between 0.1 and $0.3 \mathrm{~m}$ ) and enter Lake Lunz within $800 \mathrm{~m}$ of their flow length. All hillslopes are steep; the typical slope of the hillslopes is $29 \%$.

\section{Stream sample collection}

All six streams were sampled for DOC every two weeks in spring, summer and fall, respectively and approx. every four weeks in wintertime from July 2017 to end of June 


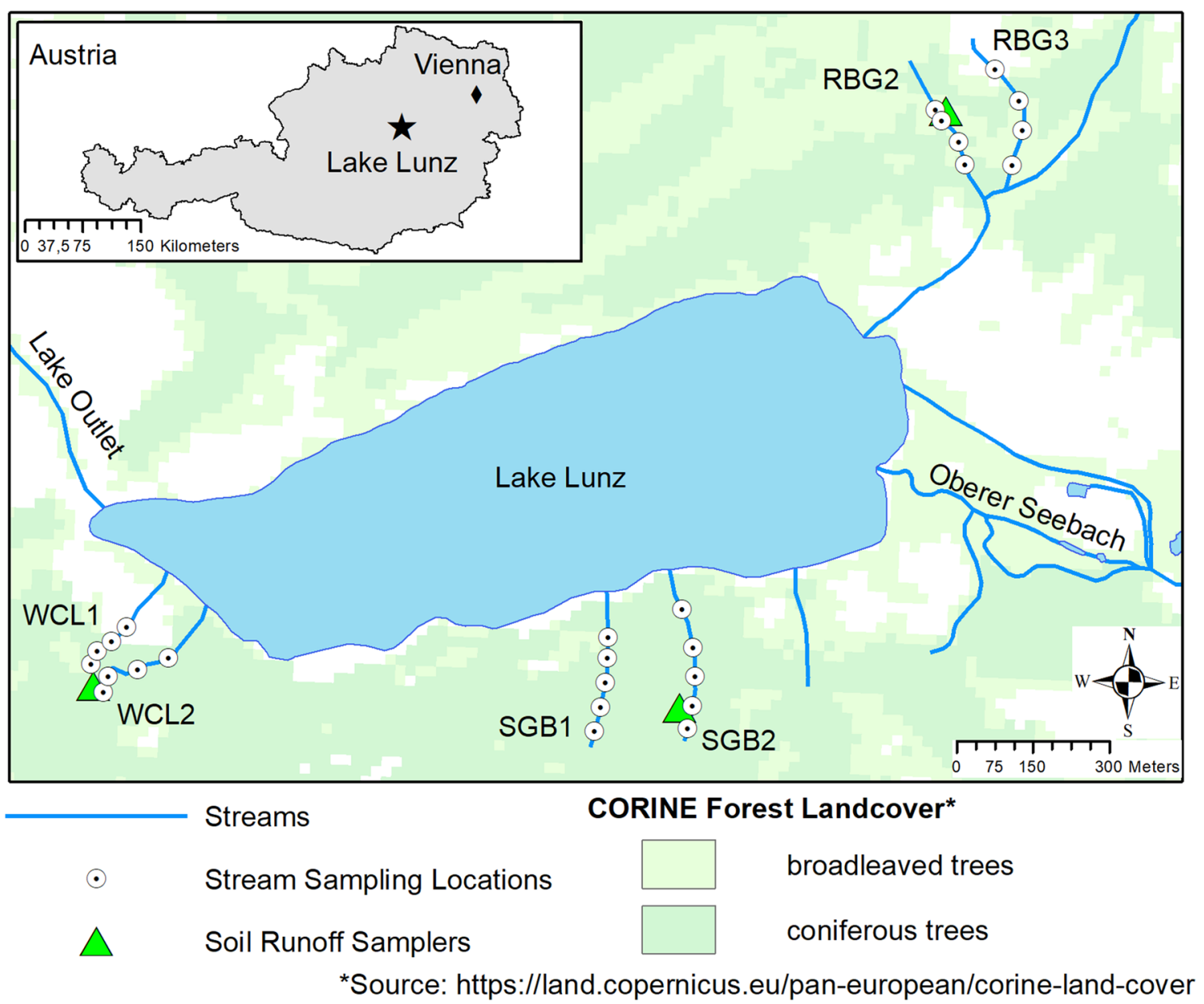

Fig. 1 Locations of sampled first order streams near Lake Lunz in Austria. Dots represent stream sampling stations and green squares soil runoff samplers (color figure online)

2019. Analyses of bacterial abundances started in May 2018. Additional samplings were performed during and following high flow events in order to characterize those events and compare the dynamics of the soil/stream connectivity at different flow conditions. At each sampling, the same four to five locations along each stream, with an approximate distance of $35 \mathrm{~m}$ between sites were sampled (Fig. 1).

The three hillslopes differed in orientation, aspect and land use (Fig. 1). WCL and SBG are located on a northfacing forested mountainside, whereas the RGB streams face towards the southwest. Land use of the SBG streams is mixed deciduous forest, with little forestry activity during the last two decades. The WCL hillslope is similarly forested, but WCL1 enters an open meadow towards the lake. Also, both WCL streams were temporarily affected by forestry machinery crossing the stream in summer 2017. Land cover of the RGB streams is also forest, except an open meadow uphill of RGB3, which is used for low intensity cattle grazing during summer.

\section{Soil runoff collection}

Soil water was collected at two different soil depths (approximately 30 and $50 \mathrm{~cm}$, referred to $A$ and $B$, respectively in the following) from each hillslope (RBG, SBG, and WCL). These samples were drawn from soil runoff samplers, which were permanently installed in wet locations in close proximity $(<15 \mathrm{~m})$ to at least one of the two streams on each hillslope (Fig. 1). Each soil runoff sampler consisted of two stainless steel soil water collectors of $2 \mathrm{~m}$ width. The collectors were pressed laterally (angle approx. $10^{\circ}$ to allow water flow) into the hillslope $(30-40 \mathrm{~cm})$ at the respective depth and the outflow covered by a thick plastic tarp. The samplers intercept soil water from the unsaturated zone of the soil profile as it drains downwards along the hillslope. 
The sampling of the soil samplers was then performed by placing acid washed and pre-combusted $\left(4 \mathrm{~h}\right.$ at $\left.\sim 450{ }^{\circ} \mathrm{C}\right)$ $2 \mathrm{~L} \mathrm{Schott} \mathrm{bottles} \mathrm{below} \mathrm{the} \mathrm{outflow} \mathrm{of} \mathrm{each} \mathrm{sampler} \mathrm{the} \mathrm{day}$ before sampling. Sampling was then done by homogenizing the content of the Schott bottles and filtering samples of soil water, similar to stream samples. During many occasions, Schott bottles were overflowing at the time of sampling, while at the driest summer conditions, some soil samplers also remained dry.

\section{DOC sampling}

Stream water samples were filtered in the field on $0.7 \mu \mathrm{m}$ pre-combusted glass-fiber filters (Whatmann GF/F) into $40 \mathrm{~mL}$ glass vials using a syringe and syringe-type filter holders. Vials were prepared 'organic carbon free' by acidwashing and subsequent combustion $\left(450{ }^{\circ} \mathrm{C}, 4 \mathrm{~h}\right)$. The filtrate was analysed for DOC concentration within $24 \mathrm{~h}$ following sampling using a Sievers 900 TOC Analyser (GE Analytical Instruments, Boulder, CO, USA) operated with an inorganic removal unit.

\section{Bacterial cells counting}

Unfiltered water samples were fixed for $2 \mathrm{~h}$ with paraformaldehyde (1\% final sample concentration) within $6 \mathrm{~h}$ after sampling. Fixed samples were then diluted 1:2 for stream water and 1:10 for soil runoff water using deionised and sterile ultrapure water. In order to separate bacteria from larger inorganic particles, samples were sonicated in a bath for $5 \mathrm{~min}$ and immediately filtered using sterile bolting cloth of $20 \mu \mathrm{m}$ mesh-size. This method yields the total number of bacteria in the water column, independent of their potential bond to a particle. The filtrate was kept at $4{ }^{\circ} \mathrm{C}$ until counting, which was done within $48 \mathrm{~h}$.

SYBR Green I was prepared by diluting a $10,000 \times$ stock solution (prod. nr. 7563; Invitrogen, Life Technologies, Paisley, UK) with sterile Tris EDTA buffer (AMRESCO Inc., Solon, OH, USA) to a concentration of $100 \times$ and was used to stain the samples at a final concentration of $1 \times$. Dye was stored at $-20{ }^{\circ} \mathrm{C}$. The staining was performed in the dark for at least $20 \mathrm{~min}$ prior to analysis. All measurements were performed with a Beckman Coulter CytoFLEX flow cytometer (Beckman Coulter GmbH, Krefeld, Germany) equipped with a laser providing $50 \mathrm{~mW}$ at $488 \mathrm{~nm}$ and five different fluorescent channels. The threshold to trigger events was set in green fluorescence $(525 \mathrm{~nm})$ as stained bacteria would emit green light when excited with blue $(488 \mathrm{~nm})$. Bacterial cells were discriminated from the background using previously measured unstained samples and green fluorescence versus side scatter dot plots.

\section{Hydrology}

We obtained precipitation data from the records of the meteorological station at the Biological Station Lunz operated by the Zentralanstalt für Meteorologie und Geodynamik (ZAMG), Austria. Daily values represent the accumulated precipitation (in $\mathrm{mm}$ ) for the past $24 \mathrm{~h}$, measured at $7 \mathrm{am}$ CET.

Variability in stream runoff was analysed using data from the Oberer Seebach station at the inlet of Lake Lunz (Fasching et al. 2015). As such, this station is located upstream of the study streams which drain directly into Lake Lunz (Fig. 1). However, the Oberer Seebach station was assumed more representative of headwater streams as compared to the station at the lake outlet. Stream discharge $\left(Q\right.$ in $\left.\mathrm{m}^{3} \mathrm{~s}^{-1}\right)$ was derived from 10 min water level measurements by using well established rating curves (Fasching et al. 2015). From these data, daily average discharge was calculated and used for further analysis. As some data were missing due to malfunctioning of logger systems, missing daily discharge values were estimated from the gage at the lake outlet $\left(R^{2}=0.91\right.$ for daily $Q$ 's from both stations).

We classified flow conditions by the level of stream discharge. Based on daily average discharge on the whole study period, we defined discharge higher than $90 \%$ of the time $\left(Q>1.86 \mathrm{~m}^{3} \mathrm{~s}^{-1}\right)$ as high flow. This classification based on the flow percentile is similar to the definition used in earlier work at the OSB (Fasching et al. 2015). However, we note that our threshold value is different, due to different hydrological conditions during our study period as compared to the earlier study. Similarly, low flow was defined as all discharge lower than the high flow threshold $\left(Q \leq 1.86 \mathrm{~m}^{3} \mathrm{~s}^{-1}\right)$, thus effectively representing intermediate and low flows.

\section{Data analysis}

DOC concentrations and bacterial abundances were tested for differences between high and low flows. In order to avoid statistical inconsistencies due to the nested sampling design, only a mean value of DOC concentrations and bacterial abundance per stream and sampling event was used for this comparison. Tests for normal distribution were conducted using the Shapiro-Wilk test. As the results indicated non-normal data, we performed non-parametric Mann-Whitney $U$ test to compare the average difference in DOC concentrations and bacterial abundances between high flow and low flow. We considered $p<0.05$ as significant and $p<0.001$ as highly significant. To compare the correlation between DOC and bacterial abundances from stream water with the one from soil water, we used an analysis of covariance with the type of sample as the nominal variable. Because of the large range of values measured for both DOC concentrations and bacterial 
abundances, data were $\log$-transformed $\left(\log _{10}\right)$ before the analysis. When seasonal comparisons (also Mann-Whitney $U$ test) were carried out, seasons were defined similar to earlier work (Fasching et al. 2015) by the month as follows: Spring from 01.03 to 31.05 ; summer from 01.06 to 31.08 ; autumn from 01.09 to 30.11 ; and winter from 01.12 to $28-29.02$.

\section{Results}

\section{DOC concentrations}

DOC concentrations ranged from 0.39 to $5.56 \mathrm{mg} \mathrm{L}^{-1}$ with an overall mean and standard deviation of $1.16 \pm 0.56 \mathrm{mg}$
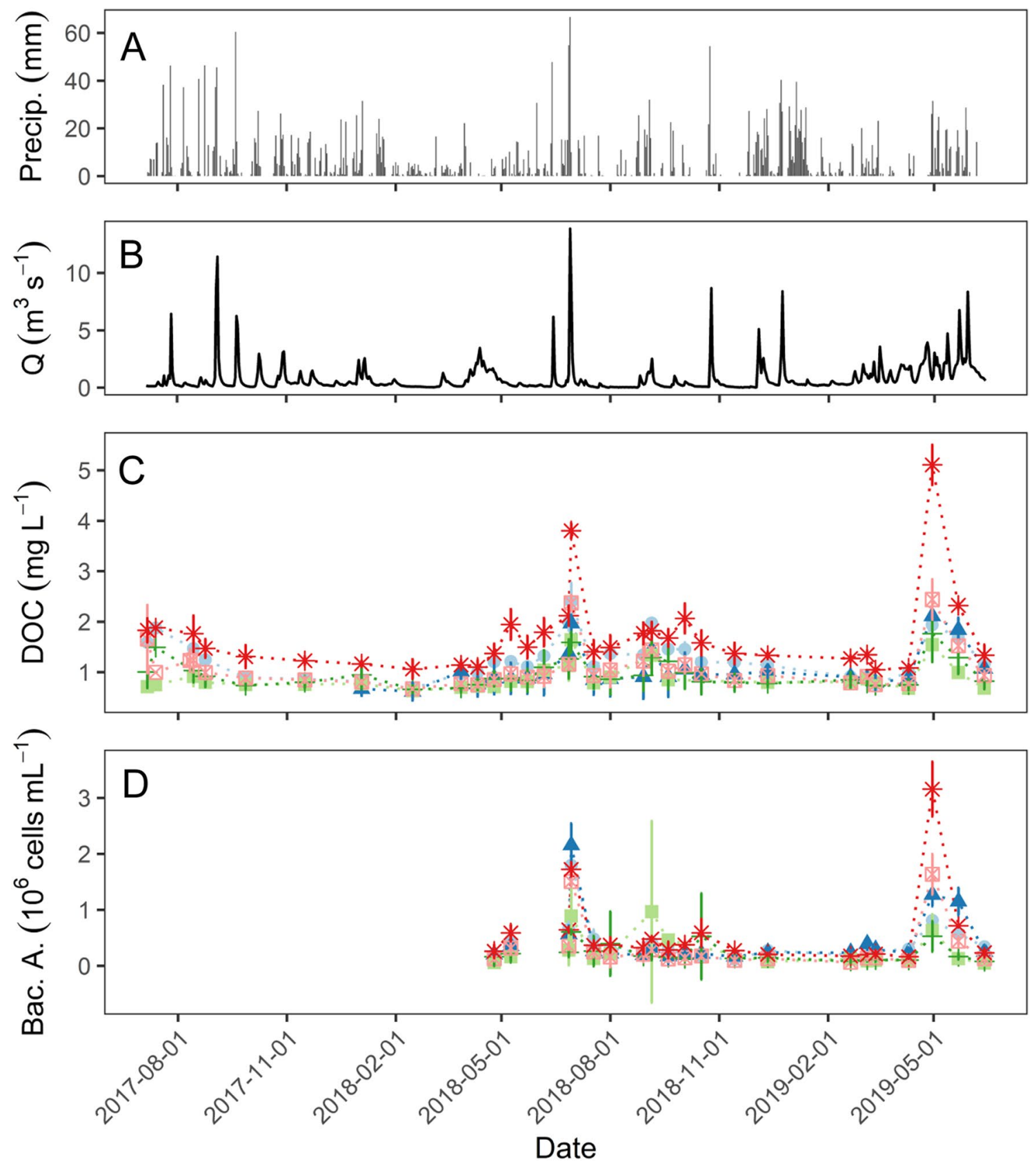

Fig. 2 a Daily precipitation and $\mathbf{b}$ daily discharge in the OSB, $\mathbf{c}$ DOC concentrations and d bacterial abundances throughout the study years. Symbols denote the streams as follows: blue dots RBG2, blue triangles RBG3, green filled squares SBG1, green pluses SBG2, red crossed squares WCL1 and red stars WCL2. Each symbol repre- sents a mean, bars the standard deviation of all samples taken along each stream during one sampling occasion, respectively. The dataset includes a total number of 811 DOC samples and 547 bacterial samples (color figure online) 

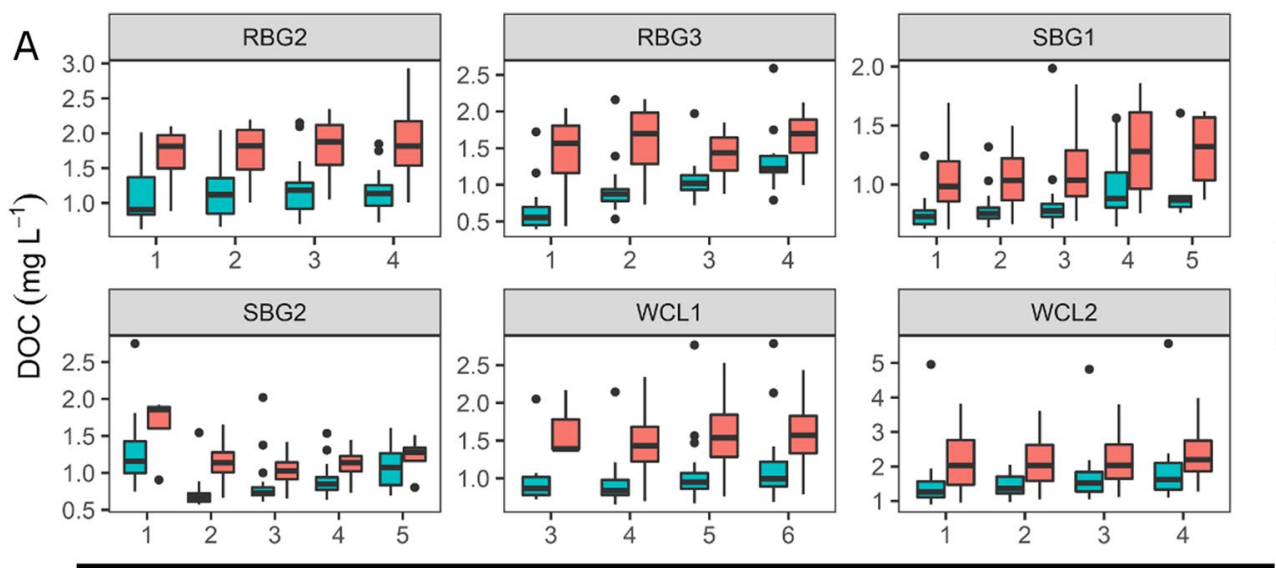

Flow conditions

宁 Low

High
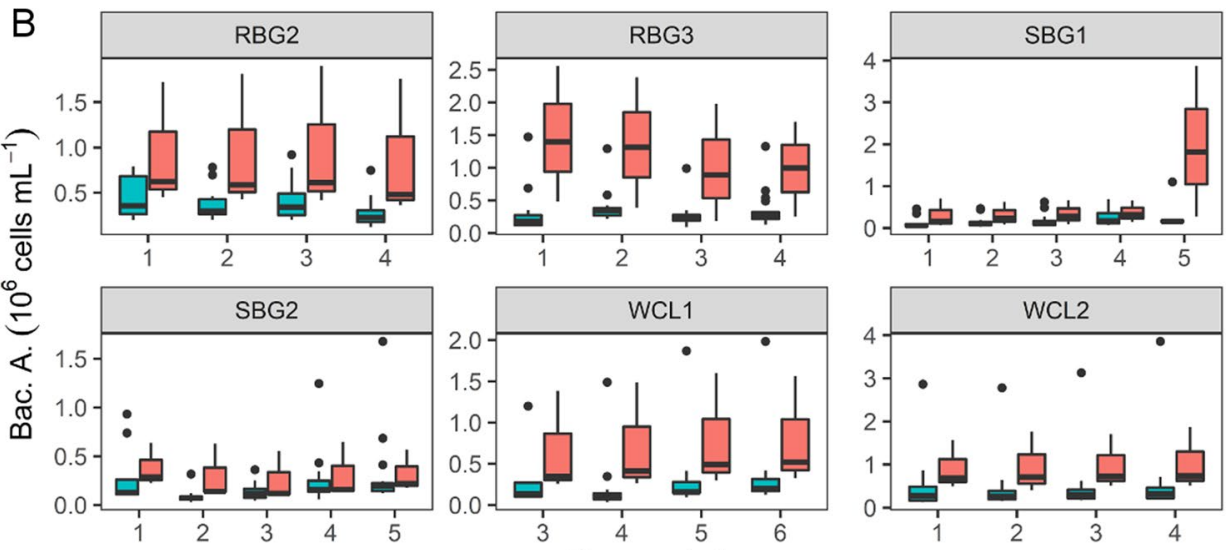

Flow conditions
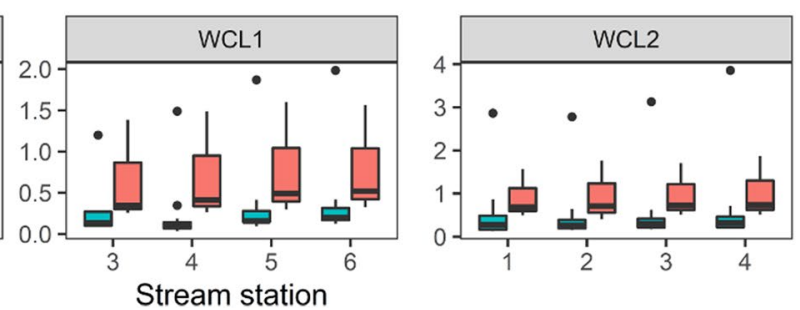

臽 Low

Fig. 3 a Changes of DOC concentrations and $\mathbf{b}$ of bacterial abundances along the flow path of the six headwater streams at low and high flow conditions. Station numbers at $\mathrm{X}$ denote the location along the flow length, with one being closest to the streams source, while

$\mathrm{L}^{-1}$ in stream water throughout the study period (Fig. 2). All streams presented an increase in DOC concentration of on average $17.9 \%$ between the most upstream and the most downstream sampling locations (Fig. 3a). This increase along the streams' flow path was significant during low flow conditions $(+18.1 \%$, Mann-Whitney $U, p<0.001)$ but not during high flow conditions $(+4.4 \%, p=1)$. Further, stream DOC was found to be lower during the winter-with a mean concentration of $0.87 \pm 0.2 \mathrm{mg} \mathrm{L}^{-1}$-and higher during autumn and summer-with respective means of $1.16 \pm 0.35$ and $1.31 \pm 0.53 \mathrm{mg} \mathrm{L}^{-1}$. The higher values were measured during high flow events, especially summer storms (Fig. 4a). During storms, the mean DOC concentration increased significantly by $44 \%$ (Mann-Whitney $U$, $p<0.001)$, from $1.1 \pm 0.36$ to $1.57 \pm 0.7 \mathrm{mg} \mathrm{L}^{-1}$ as compared to low flow conditions.

In soil runoff, measured DOC concentrations were significantly higher than in streams, ranging from 0.98 to $36.9 \mathrm{mg} \mathrm{L}^{-1}$ with an overall mean of $9.37 \pm 8.21 \mathrm{mg} \mathrm{L}^{-1}$, being eight times higher than the overall stream average. the highest number is closest to the outlet to Lake Lunz. Horizontal lines show the median, boxes the 25 th to 75 th percentiles, whiskers the 5 th to 95 th percentile range. Black dots are values outside the interquartile range

However, in soil water, DOC concentrations were not found to differ significantly between high flow and low flow conditions (Mann-Whitney $U, p=0.9$ ) and seasons (pairwise Mann-Whitney $U, p=0.38$ ) (Fig. 4c).

\section{Bacterial abundances}

Bacterial abundances ranged from 19,300 to $3,862,800$ cells $\mathrm{mL}^{-1}$ with an overall mean of $394,000 \pm 509,000$ cells $\mathrm{mL}^{-1}$ in stream water throughout the year (Fig. 2). Concentrations were found to be lower during winterwith a mean abundance of $162,900 \pm 69,500$ cells $\mathrm{mL}^{-1}$ and higher during summer-with a mean abundance of $488,700 \pm 514,400$ cells $\mathrm{mL}^{-1}$. In contrast to DOC, only some streams showed an increase in bacterial abundances between the most upstream and the most downstream sampling locations, while in others no consistent pattern was visible (Fig. 3b). Similar to DOC, high values were measured during high flow events (Fig. 4b), during which the mean bacterial abundance in streams 
Fig. 4 Boxplots of a DOC concentration and $\mathbf{b}$ bacterial abundances in streams, and c DOC concentration and $\mathbf{d}$ bacterial abundances in soils at low flow $(\mathrm{L})$ and high flow $(\mathrm{H})$, respectively. Boxplot definitions are the same as in Fig. 3
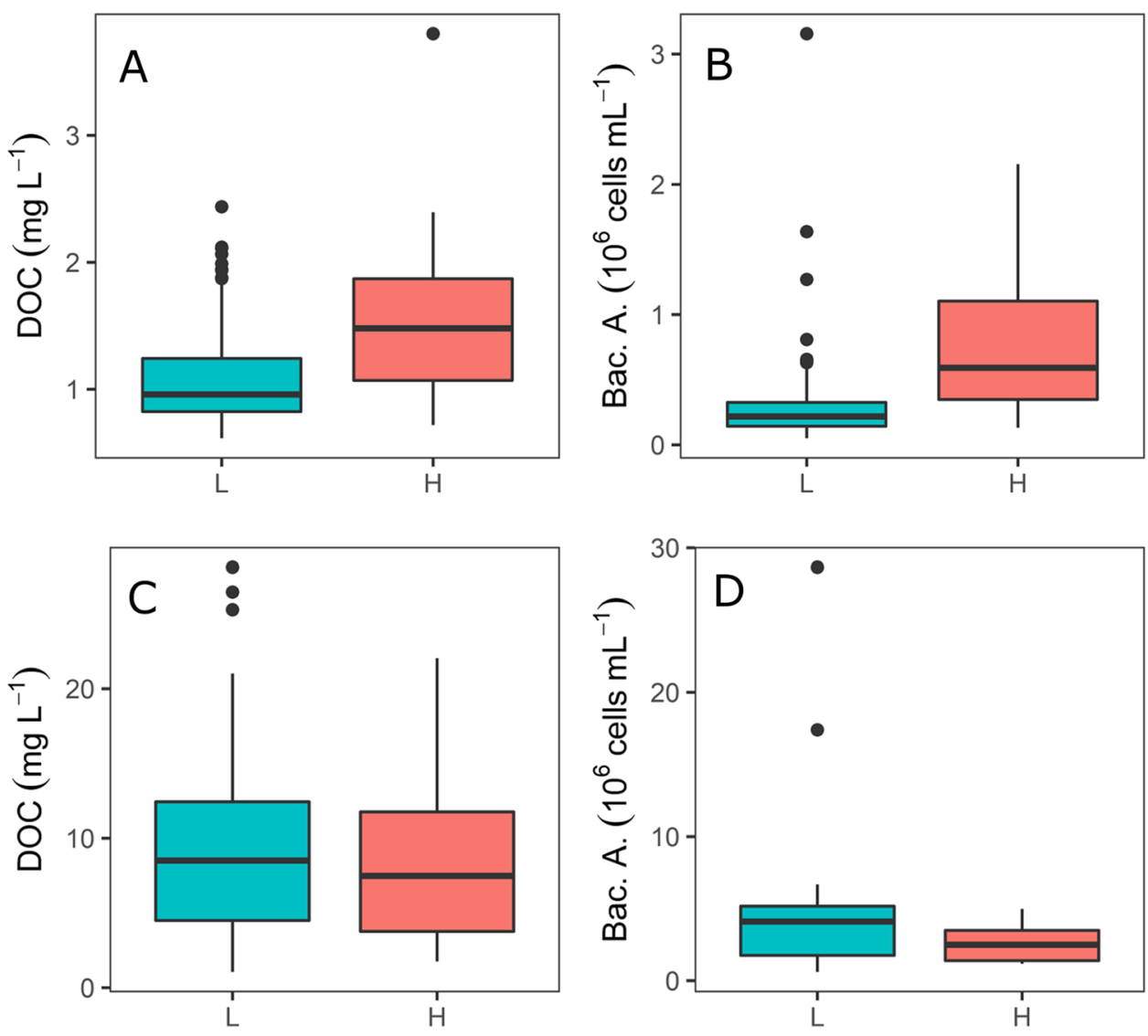

Flow conditions

increased significantly by $164.5 \%$ (Mann-Whitney $U$, $p<0.001$ ), from $304,700 \pm 372,400$ to $806,100 \pm 620,700$ cells $\mathrm{mL}^{-1}$ as compared to low flow conditions. In soil runoff, measured bacterial abundances were significantly higher than in streams $(p<0.001)$, ranging from 327,300 to $35,412,300$ cells $\mathrm{mL}^{-1}$ with a mean of $4,450,400 \pm 5,985,200$ cells $\mathrm{mL}^{-1}$, being $\sim 10$ times higher than the overall stream average. Similar to DOC, bacterial abundances were not found to be significantly different between high flow and low flow conditions in soil water (Fig. 4d).

\section{Correlation between DOC and bacterial abundance}

We investigated the relationship between DOC concentration and bacterial abundance in stream and soil water (Fig. 5). $\log _{10}$ DOC was found to be positively correlated with $\log _{10}$ bacterial abundance in stream water $\left(r^{2}=0.61\right.$, $p<0.001)$ and also in soil water $\left(r^{2}=0.34, p<0.05\right)$. The slopes of the regression lines were significantly different $(0.35$ for stream and 0.47 for soil water, respectively, $p<0.01)$ as well as their $\mathrm{y}$-intercept $(p<0.001)$.

\section{Discussion}

The major finding of this study is that the mobilization of bacteria from catchment soils to headwater streams is controlled by hydrological variability. Specifically, we provide evidence that high-flow events, such as rainstorms, cause an enhancement of bacterial mobilization (Fig. 4). Further we show that the timing of increase and the magnitude are similar to the mobilization of DOC from catchment soils. But whereas the responses of DOC to storm events in first order streams have been well described in the past (Fasching et al. 2015; Hinton et al. 1998), we now demonstrate that dynamics similar to those of DOC are also controlling microbial abundances in small streams.

We observed an increase in DOC concentration at all streams along their flow length from their spring to the end of our study reach (Fig. 3a). We propose that this increase is the result of intensified soil contributions along the streams flow length. Our study was located in a karst region. Most permanently draining streams in this region are groundwater fed, as they would otherwise cease during dry spells. The increase of DOC along the streams 
Fig. $5 \log _{10}$ bacterial abundance versus $\log _{10}$ DOC concentration in stream water (green circles/dots) and soil water (open/filled triangles). Open symbols depict low flow and filled symbols high flow conditions, respectively. Shaded areas show $95 \%$ confidence levels for predictions of the linear model (color figure online)

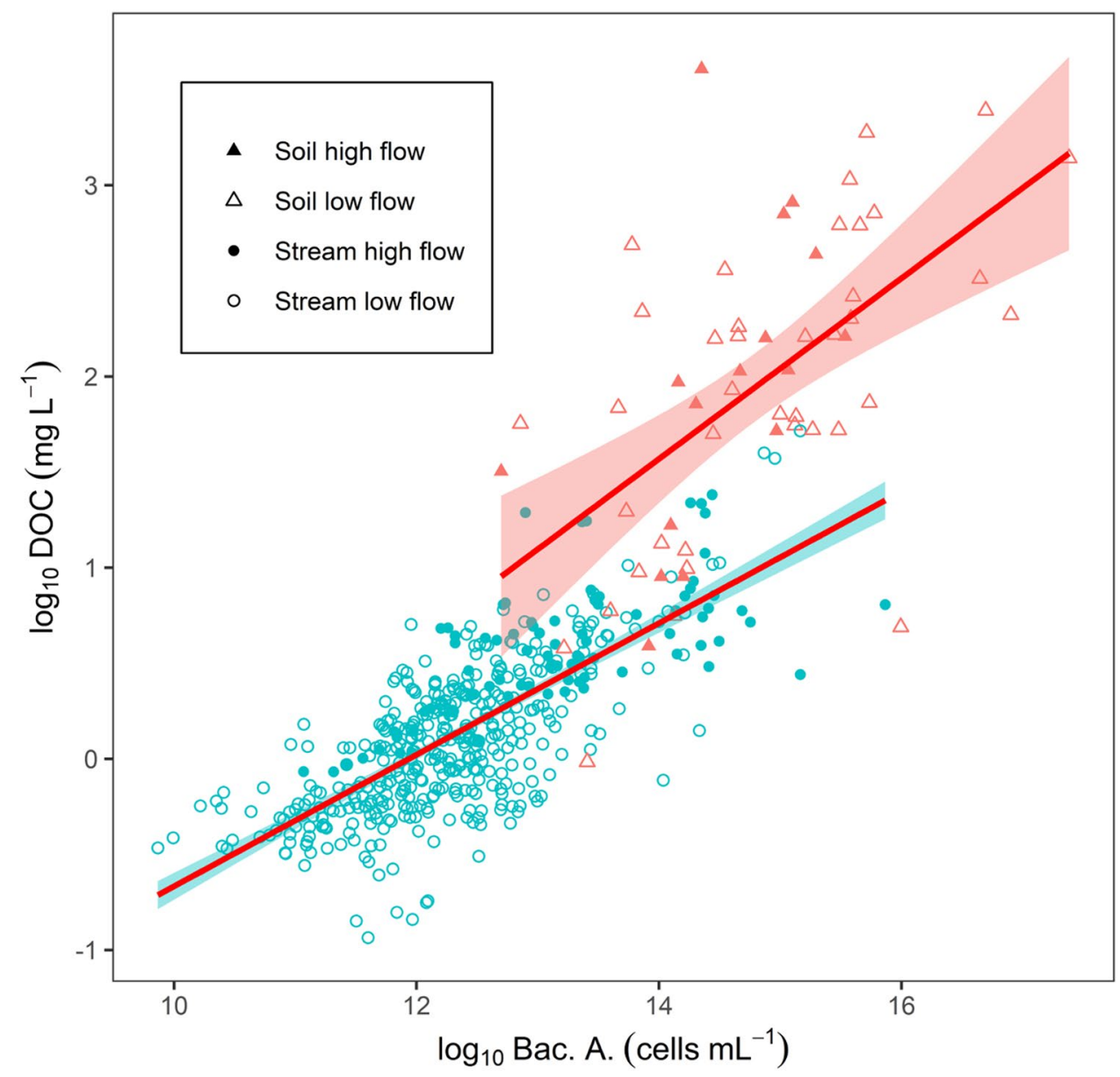

indicates that our study streams are likely fed with spring water with low DOC that is then enriched along the flow at the steep hillslope by high DOC soil water. This conceptual model contrasts somewhat with the traditional view of first order streams being a direct link between catchment soils and streams in other regions (Schelker et al. 2012).

As an alternative explanation, enrichment of DOC along the flow length could also be generated by enhanced primary production that enhances DOC concentrations, especially during spring and summer low flow (Harjung et al. 2019). However, many previous studies have shown that first order streams presented very low autochthonous primary production that accounted for less than $5 \%$ of the annual organic carbon inputs in these ecosystems (Fisher and Likens 1973; Mulholland 1997; Richardson 2019). In addition, the fact that the increase was independent of season, i.e., that it was also present during the fall and winter, makes this explanation less probable. Further, if DOC deliveries from primary production were relevant, additional variation based on light availability for stream primary producers would be expected (Dodds et al. 1996; Hall et al. 2015). Our study streams differed in their light regimes (shading by closed forest canopy at SBG1, SBG2 and RGB2, while WCL1, WCL2 and RBG3 are at least partly open, Fig. 1), as well as their aspect. However, we were unable to identify a light-induced variation in our downstream DOC pattern. Thus we conclude that increasing soil contributions along the flow length is the most probable explanation for the increasing DOC concentrations along our study streams. Interestingly, an increase in bacterial abundances along the stream flow path was also indicated for some streams (Fig. 3b) but this increase was not significant and generally weaker than the one observed for DOC concentrations. At present, we cannot explain these differences, but consider soil community dynamics or minor variations of how bacteria are mobilized from soils as compared to DOC as possible explanations. However, these minor differences appear to be overwhelmed during events resulting in synchrony in increase.

Our findings on the variation of DOC concentration and bacterial abundance with varying discharge expand our present knowledge on the dynamics of headwater streams. High flow events led to a significant increase in DOC concentration by $70.8 \%$ and in bacterial abundance by $32.4 \%$. Previous work has described the increase of DOC concentration in streams during storms following enhanced soil contributions 
(e.g., Ågren et al. 2008; Fasching et al. 2015; Hinton et al. 1998).

The link between soils and streams in terms of microbial communities has been investigated in the past using sequencing techniques (Crump et al. 2012; Ruiz-González et al. 2015; Savio et al. 2015). However, few studies have investigated the temporal dynamics of bacterial abundances in streams (Hullar et al. 2006; Richardson 2019). Here we found that high flow conditions, as they are commonly present in our study streams during rainstorms or snowmelt, caused a general increase in bacterial abundances (Fig. 4b). This pattern may be explained by increased deliveries of microbes from the catchment soils, similar to the mobilization of DOC. Alternatively high bacterial abundances could also be caused by the remobilisation of in-stream bacteria in upstream reaches. The latter would be caused by high flow velocities transiently enhancing the shear stress on benthic biofilms. The biofilm would then release bacteria during high flow (Paul et al. 2012; Stewart 1993). However, some of our observational points were located at the very source area of the first order streams (upstream length $<20 \mathrm{~m}$ ). These sites showed the same increase in bacterial abundance during events, as those further downstream. Thus we suggest that provision of microbes from upstream reaches is small, as compared to soil contributions.

The water residence time is small in the study streams, ranging from minutes to hours at the maximum. For example, we quantified a mean flow velocity of $0.1 \mathrm{~m} \mathrm{~s}^{-1}$ across a distance of $\sim 100 \mathrm{~m}$ in WCL1 at intermediate flow conditions. Assuming similar velocities for all streams suggest that the residence time in the study reaches rarely exceeds $2 \mathrm{~h}$. We argue that this is too short for relevant bacterial growth in the free flowing water column, especially during high flow events. Therefore, we attribute the dynamic increases in bacteria during runoff events in our streams to enlarged soil contributions, rather than instream growth.

Following these notions, we suggest that soil inoculation of headwater streams is a dynamic process that may be largely controlled by the intensity of hydrometeorological events. Consequently, we propose that most headwater streams are subject to a dynamic and reoccurring microbial inoculation from their catchment soils during storm events. This dynamic microbial inoculation of streams by soils may then have some impact on the development of the microbial communities in the downstream river network (Besemer et al. 2013; Ruiz-González et al. 2015; Savio et al. 2015; Widder et al. 2014). However, at present this potential impact remains largely unknown, as most previous studies on the role of soil inoculation on stream microbial communities did not consider the temporal dynamics of inoculation (Besemer et al. 2013; Monard et al. 2016; Ruiz-González et al. 2015; Widder et al. 2014).
The correlation we found between $\log _{10}$ DOC and $\log _{10}$ bacterial abundance in streams further supports our view that both constituents are mobilized concurrently from the catchment soils and that this mobilization is enhanced during high flow. The general mechanisms proposed for DOC mobilization from soils to streams include the flushing of DOC from the organic top soil (A-horizon) (Boyer et al. 1996), as well as from carbon rich riparian soils (Laudon et al. 2011; Schelker et al. 2013). Similarly, the abundance of soil bacteria has been suggested to vary with soil depth, with the highest abundance and microbial diversity present in the organic rich top soils (Fierer et al. 2003). This suggests that conceptual models developed for the mobilization of DOC from soils to streams (Boyer et al. 1996; Laudon et al. 2011; Weiler and McDonnell 2006; Zarnetske et al. 2018) could potentially also be applied to explain the variation in bacterial abundances in streams in the future. Nevertheless, the high ratio between soil-stream interfaces and water volume in headwater streams promotes transfer from soil to streams but the relationship might be weaker in larger fluvial systems. Also, pre-alpine streams have low DOC concentrations (Fasching et al. 2015) in comparison to other fluvial ecosystems, such as boreal streams (Dawson et al. 2008; Laudon et al. 2011). Further investigations must be conducted to determine if the relationship between DOC concentrations and bacterial abundances also holds true in more DOC-rich environments.

Interestingly, the strong correlation of $\log _{10}$ DOC concentration per $\log _{10}$ bacterial abundance observed in streams was also present in soil water. Although the slopes and the Y-intercepts of the linear models for soils and streams were significantly different, the general pattern of increasing $\log _{10}$ abundance with increasing $\log _{10}$ DOC remained. However, the significant differences between the relationships likely indicate fundamental differences in ecosystem structure regarding the availability of carbon versus the size of the maintained bacterial population in stream versus soil ecosystems.

Among the main distinctions between lotic and terrestrial ecosystems is the difference in the ratio between dissolved and particulate organic carbon, with a larger ratio in streams versus soils (Grimm et al. 2003). Also, primary producers show stoichiometric and lifespan differences (lower C:N and $\mathrm{P}: \mathrm{N}$ ratios, more short-lived in streams) (Grimm et al. 2003; Nowlin et al. 2008). Thus one possible explanation for the observed difference in the relationships in our oligotrophic system would be that streams can maintain higher populations of primary producers during nutrient limitation. Further, the generally higher ratio of consumers versus producers in streams (Grimm et al. 2003) could then result in the difference of higher $\log _{10}$ bacterial abundance versus $\log _{10}$ DOC. 
Alternatively, differences in the size of the maintained microbial population between soils and streams could also stem from differences in DOM composition between the two systems. In soils, degraded humic-like DOM components are typically dominant, while in streams labile, protein-like DOM is present along with humic substances (Fasching et al 2015; Hutchins et al. 2017). This could also cause a general advantage in maintaining an extended microbial population in streams.

Future research should address two main aspects. First, the precise nature of the microbial communities that are delivered from soils to streams during hydrological events. At present, the community composition of these pulses of microbial life are not well understood (Monard et al. 2016; Ruiz-González et al. 2015). Second, there is currently only limited knowledge about the relevance of the dynamic and reoccurring microbial soil inoculation for stream microbial community development in the receiving waters (Besemer et al. 2013; Widder et al. 2014).

Overall we show that soils provide a dynamic inflow of bacteria and DOC to first order streams resulting in a dynamic and reoccurring inoculation of stream microbial communities from catchment soils during runoff events. We propose that this process is potentially important for the development of microbial communities of downstream river networks. We suggest future research on the community composition and the potential downstream effects of this dynamic soil inoculation process.

Acknowledgements Open access funding provided by University of Vienna. This study was performed within the 'HYDRO-DIVERSITY' project funded by the Earth System Sciences (ESS) Program of the Austrian Academy of Sciences (ÖAW) to JS

Open Access This article is licensed under a Creative Commons Attribution 4.0 International License, which permits use, sharing, adaptation, distribution and reproduction in any medium or format, as long as you give appropriate credit to the original author(s) and the source, provide a link to the Creative Commons licence, and indicate if changes were made. The images or other third party material in this article are included in the article's Creative Commons licence, unless indicated otherwise in a credit line to the material. If material is not included in the article's Creative Commons licence and your intended use is not permitted by statutory regulation or exceeds the permitted use, you will need to obtain permission directly from the copyright holder. To view a copy of this licence, visit http://creativecommons.org/licenses/by/4.0/.

\section{References}

Ågren A, Berggren M, Laudon H, Jansson M (2008) Terrestrial export of highly bioavailable carbon from small boreal catchments in spring floods. Freshw Biol 53(5):964-972

Amaral V, Graeber D, Calliari D, Alonso C (2016) Strong linkages between DOM optical properties and main clades of aquatic bacteria. Limnol Oceanogr 61(3):906-918
Battin TJ (1999) Hydrologic flow paths control dissolved organic carbon fluxes and metabolism in an alpine stream hyporheic zone. Water Resour Res 35(10):3159-3169

Battin TJ, Kaplan LA, Findlay S, Hopkinson CS, Marti E, Packman AI, Denis Newbold J, Sabater F (2008) Biophysical controls on organic carbon fluxes in fluvial networks. Nat Geosci 1(2):95-100

Battin TJ, Besemer K, Bengtsson MM, Romani AM, Packmann AI (2016) The ecology and biogeochemistry of stream biofilms. Nat Rev Microbiol 14(4):251-263

Benda L, Hassan MA, Church M, May CL (2005) Geomorphology of steepland headwaters: the transition from hillslopes to channels. J Am Water Resour Assoc 41(4):835-851

Berggren M, del Giorgio PA (2015) Distinct patterns of microbial metabolism associated to riverine dissolved organic carbon of different source and quality. J Geophys Res Biogeosci 120:989-999

Besemer K, Singer G, Quince C, Bertuzzo E, Sloan W, Battin TJ (2013) Headwaters are critical reservoirs of microbial diversity for fluvial networks. Proc R Soc B Biol Sci 280(1771):20131760

Bishop KH, Buffman I, Erlandsson M, Fölster J, Laudon H, Seibert J, Temnerud J (2008) Aqua incognita: the unknown headwaters. Hydrol Process 22:1239-1242

Boyer EW, Hornberger GM, Bencala KE, McKnight D (1996) Overview of a simple model describing variation of dissolved organic carbon in an upland catchment. Ecol Model 86(2-3):183-188

Corine Land Cover (CLC) 2018, Version 20. https://land.copernicus .eu/pan-european/corine-land-cover/clc2018. Release date June 14, 2019. Accessed 20 Aug 2019

Crump BC, Amaral-Zettler LA, Kling GW (2012) Microbial diversity in arctic freshwaters is structured by inoculation of microbes from soils. ISME J 6(9):1629-1639

Dawson JJC, Soulsby C, Tetzlaff D, Hrachowitz M, Dunn SM, Malcolm IA (2008) Influence of hydrology and seasonality on DOC exports from three contrasting upland catchments. Biogeochemistry 90(1):93-113

Dodds WK, Hutson RE, Eichem AC, Evans MA, Gudder DA, Fritz KM, Gray L (1996) The relationship of floods, drying, flow and light to primary production and producer biomass in a Prairie stream. Hydrobiologia 333(3):151-159

Etienne P, Ochoa JC, Pechaud Y, Liu Y, Liné A (2012) Effect of shear stress and growth conditions on detachment and physical properties of biofilms. Water Res 46(17):5499-5508

Fasching C, Behounek B, Singer GA, Battin TJ (2014) Microbial degradation of terrigenous dissolved organic matter and potential consequences for carbon cycling in brown-water streams. Sci Rep 4:4981

Fasching C, Ulseth AJ, Schelker J, Steniczka G, Battin TJ (2015) Hydrology controls dissolved organic matter export and composition in an Alpine stream and its hyporheic zone. Limnol Oceanogr 61(2):558-571

Federle TW, Dobbins DC, Thornton-Manning JR, Jones DD (1986) Microbial biomass, activity, and community structure in subsurface soils. Ground Water 24(3):365-374

Fierer N (2017) Embracing the unknown: disentangling the complexities of the soil microbiome. Nat Rev Microbiol 15(10):579-590

Fierer N, Schimel JP, Holden PA (2003) Variations in microbial community composition through two soil depth profiles. Soil Biol Biochem 35(1):167-176

Findlay RH, Yeates C, Hullar MAJ, Stahl DA, Kaplan LA (2008) Biome-level biogeography of streambed microbiota. Appl Environ Microbiol 74(10):3014-3021

Fisher SG, Likens GE (1973) Energy flow in Bear Brook, New Hampshire: an integrative approach to stream ecosystem metabolism. Ecol Monogr 43(4):421-439

Gomi T, Sidle RC, Richardson JS (2002) Understanding processes and downstream linkages of headwater systems. Bioscience 52(10):905-916 
Grimm NB, Gergel SE, McDowell WH, Boyer EW, Lisa Dent C, Groffman P, Hart SC, Harvey J, Johnston C, Mayorga E, McClain ME, Pinay G (2003) Merging aquatic and terrestrial perspectives of nutrient biogeochemistry. Oecologia 137(4):485-501

Hall RO, Yackulic CB, Kennedy TA, Yard MD, Rosi-Marshall EJ, Voichick N, Behn KE (2015) Turbidity, light, temperature, and hydropeaking control primary productivity in the Colorado River, Grand Canyon. Limnol Oceanogr 60(2):512-526

Harjung A, Ejarque E, Battin T, Butturini A, Sabater F, Stadler M, Schelker J (2019) Experimental evidence reveals impact of drought periods on dissolved organic matter quality and ecosystem metabolism in Subalpine Streams. Limnol Oceanogr 64(1):46-60

Hassell N, Tinker KA, Moore T, Ottesen EA (2018) Temporal and spatial dynamics in microbial community composition within a temperate stream network. Environ Microbiol 20(10):3560-3572

Hermans SM, Buckley HL, Case BS, Lear G (2019) Connecting through space and time: catchment-scale distributions of bacteria in soil, stream water and sediment. Environ Microbiol 22:1000-1010

Hinton MJ, Schiff SL, English MC (1998) Sources and flowpaths of dissolved organic carbon during storms in two forested watersheds of the precambrian shield. Biogeochemistry 41:175-197

Hullar MAJ, Kaplan LA, Stahl DA (2006) Recurring seasonal dynamics of microbial communities in stream habitats. Appl Environ Microbiol 72(1):713-722

Hutchins RHS, Aukes P, Schiff SL, Dittmar T, Prairie YT, del Giorgio PA (2017) The optical, chemical, and molecular dissolved organic matter succession along a Boreal Soil-stream-river continuum. J Geophys Res Biogeosci 122(11):2892-2908

Köhler SJ, Buffam I, Seibert J, Bishop KH, Laudon H (2009) Dynamics of stream water TOC concentrations in a Boreal headwater catchment: controlling factors and implications for climate scenarios. J Hydrol 373(1-2):44-56

Laudon H, Köhler S, Buffam I (2004) Seasonal TOC export from seven Boreal catchments in Northern Sweden. Aquat Sci 66(2):223-230

Laudon H, Berggren M, Ågren A, Buffam I, Bishop KH, Grabs T, Jansson M, Köhler S (2011) Patterns and dynamics of dissolved organic carbon (DOC) in Boreal Streams: the role of processes, connectivity, and scaling. Ecosystems 14(6):880-893

Monard C, Gantner S, Bertilsson S, Hallin S, Stenlid J (2016) Habitat generalists and specialists in microbial communities across a terrestrial-freshwater gradient. Sci Rep 6:37719

Mulholland PJ (1997) Organic matter dynamics in the West Fork of Walker Branch, Tennessee, USA. J N Am Benthol Soc 16(1):61-67

Nowlin WH, Vanni MJ, Yang LH (2008) Comparing resource pulses in aquatic and terrestrial ecosystems. Ecology 89(3):647-659

Philippot L, Spor A, Hénault C, Bru D, Bizouard F, Jones CM, Sarr A, Maron PA (2013) Loss in microbial diversity affects nitrogen cycling in soil. ISME J 7(8):1609-1619

Raymond PA, Hartmann J, Lauerwald R, Sobek S, McDonald C, Hoover M, Butman D, Striegl R, Mayorga E, Humborg C, Kortelainen P, Dürr H, Meybeck M, Ciais P, Guth P (2013) Global carbon dioxide emissions from inland waters. Nature 503(7476):355-359

Richardson JS (2019) Biological diversity in headwater streams. Water (Switzerland) 11(2):366

Richardson JS, Danehy RJ (2007) A synthesis of the ecology of headwater streams and their Riparian zones in temperate forests. For Sci 53(2):131-147

Ruiz-González C, Niño-García JP, del Giorgio PA (2015) Terrestrial origin of bacterial communities in complex boreal freshwater networks. Ecol Lett 18(11):1198-1206
Savio D, Sinclair L, Ijaz UZ, Parajka J, Reischer GH, Stadler P, Blaschke AP, Blöschl G, Mach RL, Kirschner AKT, Farnleitner AH, Eiler A (2015) Bacterial diversity along a $2600 \mathrm{~km}$ river continuum. Environ Microbiol 17(12):4994-5007

Schelker J, Eklöf K, Bishop K, Laudon H (2012) Effects of forestry operations on dissolved organic carbon concentrations and export in boreal first-order streams. J Geophys Res Biogeosci 117(1):1-12

Schelker J, Grabs T, Bishop K, Laudon H (2013) Drivers of increased organic carbon concentrations in stream water following forest disturbance: separating effects of changes in flow pathways and soil warming. J Geophys Res Biogeosci 118(4):1814-1827

Schelker J, Singer GA, Ulseth AJ, Hengsberger S, Battin TJ (2016) $\mathrm{CO} 2$ Evasion from a steep, high gradient stream network: importance of seasonal and diurnal variation in aquatic $\mathrm{PCO} 2$ and gas transfer. Limnol Oceanogr 61(5):1826-1838

Schumm SA (1956) Evolution of drainage systems and slopes in Badlands at Perth Amboy, New Jersey. Bull Geol Soc Am 67(5):597-646

Sidle RC, Tsuboyama Y, Noguchi S, Hosoda I, Fujieda M, Shimizu $\mathrm{T}$ (2000) Stormflow generation in steep forested headwaters: a linked hydrogeomorphic paradigm. Hydrol Process 14:369-385

Stewart PS (1993) A model of biofilm detachment. Biotechnol Bioeng 41(1):111-117

Taylor JP, Wilson B, Mills MS, Burns RG (2002) Comparison of microbial numbers and enzymatic activities in surface soils and subsoils using various techniques. Soil Biol Biochem 34(3):387-401

Teachey ME, McDonald JM, Ottesen EA (2019) Rapid and stable microbial community assembly in the headwaters of a third-order stream. Appl Environ Microbiol 85(11):1-15

Wagg C, Franz Bender S, Widmer F, van der Heijden MGA (2014) Soil biodiversity and soil community composition determine ecosystem multifunctionality. Proc Natl Acad Sci USA 111(14):5266-5270

Weiler M, McDonnell JJ (2006) Testing nutrient flushing hypotheses at the hillslope scale: a virtual experiment approach. J Hydrol 319(1-4):339-356

Widder S, Besemer K, Singer GA, Ceola S, Bertuzzo E, Quince C, Sloan WT, Rinaldo A, Battin TJ (2014) Fluvial network organization imprints on microbial co-occurrence networks. Proc Natl Acad Sci USA 111(35):12799-12804

Williams PJB, Del Giorgio PA (2005) Respiration in aquatic ecosystems: history and background. In: Del Giorgio PA, Williams P (eds) Respiration in aquatic ecosystems. Oxford Scholarship Online, Oxford, pp 1-17

Wipfli MS, Richardson JS, Naiman RJ (2007) Ecological linkages between headwaters and downstream ecosystems: transport of organic matter, invertebrates, and wood down headwater channels. J Am Water Resour Assoc 43(1):72-85

Zarnetske JP, Bouda M, Abbott BW, Saiers J, Raymond PA (2018) Generality of hydrologic transport limitation of watershed organic carbon flux across ecoregions of the United States. Geophys Res Lett 45(21):11702-11711

Publisher's Note Springer Nature remains neutral with regard to jurisdictional claims in published maps and institutional affiliations. 